\title{
The effect of enzymatic hydrolysis on the antioxidant activities and amino acid profiles of defatted chia (Salvia hispanica $L$.) flour
}

\author{
Ibrahim, E.S.K. and *Ghani, M.A. \\ Food Science Department, Faculty of Science and Technology, Universiti Kebangsaan Malaysia 43600 \\ Bangi, Selangor, Malaysia
}

\begin{abstract}
Article history:
Received: 21 May 2020

Received in revised form: 21

August 2020

Accepted: 6 November 2020

Available Online: 6

December 2020

Keywords:

Antioxidant,

Defatted chia flour,

Enzymatic hydrolysis,

Protein extraction,

Protein hydrolysates,

Amino acid profile.
\end{abstract}

\section{DOI:}

https://doi.org/10.26656/fr.2017.4(S4).003

\begin{abstract}
The aim of this study was to determine the effect of enzymatic hydrolysis using different proteases (Alcalase ${ }^{\circledR}$ and papain) and hydrolysis period on antioxidative activities and amino acid profiles of hydrolysed chia peptides. The experiment has been carried out using a completely randomized block design. The protein from defatted chia flour (DCF) was first isolated using different extraction $\mathrm{pH}(\mathrm{pH} 10 ; 11 ; 12)$ and precipitation $\mathrm{pH}(\mathrm{pH}$ $3.5,4.0$ and 4.5) to determine the highest protein isolated (CI) yield. The chia isolate (CI) extracted using the combination treatment $(\mathrm{pH} \mathrm{12,3.5)} \mathrm{demonstrated} \mathrm{the} \mathrm{highest} \mathrm{protein}$ content of $17.22 \%$ and was selected to further hydrolysed using Alcalase ${ }^{\circledR}$ and papain enzyme at different hydrolysis time. The degree of hydrolysis $(\mathrm{DH})$, protein solubility and peptide content of the chia protein hydrolysates $(\mathrm{CH})$ were observed. Alcalase ${ }^{\circledR}-\mathrm{CH}$ and Papain- $\mathrm{CH}$ demonstrated the highest $\mathrm{DH}$ at 60 mins of hydrolysis with the value of $47.09 \%$ and $44.29 \%$, respectively. The protein solubility and peptide content were directly proportional to the $\mathrm{DH}$. The Alcalase ${ }^{\circledR}-\mathrm{CH}$ hydrolysed at 60 mins exhibited the highest antioxidant activities as measured by DPPH, ABTS and FRAP assays with values of $35.46 \mu \mathrm{M}$ AAE, $34.45 \mu \mathrm{M}$ TE and $23.11 \mu \mathrm{M} \mathrm{FeSO}_{4} .7 \mathrm{H}_{2} \mathrm{O}$ E, respectively. The Alcalase ${ }^{\circledR}-$ $\mathrm{CH}$ demonstrated higher $(\mathrm{p}<0.05)$ hydrophobic amino acid $(42.51 \%)$ compared to and Papain-CH $(37.25 \%$,). The highest aromatic amino acid content also recorded by Alcalase ${ }^{\circledR}-\mathrm{CH}(20.10 \%)$, whereas Papain-CH with the value of $15.54 \%$. However, both $\mathrm{CH}$ exhibited higher hydrophilic and aromatic amino acid compared to DCF and CI. This result has proved that the enzymatic hydrolysis of $\mathrm{CH}$ using Alcalase ${ }^{\circledR}$ and papain improved the nutritional and antioxidant capabilities, thus potentially represent a naturally occurring antioxidant ingredient in the production of functional food and nutraceutical appliance with significant health benefits.
\end{abstract}

\section{Introduction}

Free radicals are freely formed during normal metabolic processes, and they are a major factor in the development of diseases such as cancer and other cardiovascular diseases (Lobo et al., 2010). The human body can synthesize its defence system against the free radicals but not sufficiently effective to prevent the damage (Makinen et al., 2012). Hence, the need for consumption of antioxidant-rich food such as antioxidative peptides basically to protect the human body against oxidative damage and consequently associated diseases. Many synthetic antioxidants are used as a free radical scavenger in the food and pharmaceutical industries (Najafian and Babji, 2012). However, they cannot proffer total protection against oxidative stress (Poljsak et al., 2013), and are viewed to have a possible toxic effect which has spurred research interest especially in the discovery of natural antioxidants from plant foods which are more compatible with human nature (Taghvaei and Jafari, 2015).

Some food-derived proteins have potential as a natural source of producing antioxidative peptides. However, these proteins are inactive in the intact form within the food matrix due to their large size and conformational arrangement that buries hydrophobic or reactive groups inside the protein structure (Garcia et al., 2013). Enzymatic hydrolysis is a process that was highly potential to release the bioactive peptides from parental protein and exhibiting various biological activities and nutritional (Lee et al., 2010). Bioactive peptides exhibit different physicochemical properties and biological activities, depending on their amino acid composition 
(Kim and Wijesekara, 2010). The antioxidative peptides contain 2 to 20 amino acid units and usually are inactive within the sequences of their parent protein but can be released by enzymatic hydrolysis (Shahidi and Zhong, 2008).

Chia seed (Salvia hispanica L) is a herbaceous plant belonging to the mint family (Munoz et al., 2013) and often referred under its common name 'chia'. It is one of the non-conventional protein sources which have been increasingly studied in recent years (Fernández-López et al., 2018). Generally, chia is rich in polyunsaturated fatty acids (PUFA) and lipophilic phytochemicals such as tocopherols or vitamin E (Nitrayova et al., 2014). Besides the oil component, in general, chia seeds comprise $17 \%-24 \%$ protein (Sandoval-Oliveros and Paredez-Lopez, 2013), make it a new potential of plantbased protein source. Chia seed protein contains four different fractions, among which globulins are the major components, and albumins, glutelins and prolamins are present in almost equal proportion (Sandoval-Oliveros and Paredez-Lopez, 2013). These proteins are readily digestible (Sandoval-Oliveros and Paredez-Lopez, 2013) and possess good foaming and excellent water and oil holding capacities (Olivos-Lugo et al., 2010). Chia seed proteins contain all the essential amino acids, and the percentage of glutamic acid, arginine and aspartic acid were very high (Sandoval-Oliveros and Paredez-Lopez, 2013). Currently, the utilization of chia focuses on the extraction of chia oil. Industrial production for chia oil generates waste, presently used in the manufacturing of defatted chia flour (DCF) and animal feed, these being low-cost products. This provides a new research area on the utilization of protein from the DCF industrial waste as a strategy used to add value to this by-product.

There are various good claimed on chia see, especially its benefits to human health. However, there are still not many published studies on the bioactivities of chia peptides produced via enzymatic hydrolysis, mainly the potential as an antioxidant. Thus, the objective of this study is to determine the antioxidant activities and amino acid profiles of chia hydrolysates enzymatically hydrolyzed using different protease enzymes (Alcalase ${ }^{\circledR}$ and papain) at a different time of hydrolysis. The enzymatic hydrolysis of CI using an Alcalase ${ }^{\circledR}$ and papain was expected to produce the $\mathrm{CH}$ with better nutritional quality and can be used as a new natural antioxidant plant-based protein source.

\section{Materials and methods}

\subsection{Materials}

The DCF was supplied by The Chia Co (Australia). The Alcalase ${ }^{\circledR}$ from Bacillus lechinoformis $(\geq 2.4 \mathrm{U} / \mathrm{g})$ and papain from Carica papaya (30 U/mg) were supplied by Sigma-Aldrich (USA). All other reagents used were of analytical grade were from Sigma Aldrich (USA).

\subsection{Protein isolation}

The method of protein isolation as reported by Lopez et al. (2017) was used to produce the CI. Before the protein extraction is performed, the DCF sample was first demucilaged. The DCF was mixed with distilled water (with a ratio of 1:20), stirred for 30 mins and centrifuged at $10,000 \times g$ for 15 mins. The mucilaginous intermediate phase of the slurry was removed, while the chia proteins were recovered in the upper aqueous phase and the bottom phase. The demucilaged DCF was then dispersed in different $\mathrm{pH}$ of alkaline water $(\mathrm{pH} \mathrm{10} ; \mathrm{pH}$ 11; $\mathrm{pH}$ 12) using a DCF-to-water ratio of 1:20 to extract the protein. This slurry was stirred at ambient temperature for $1 \mathrm{hr}$ using a magnetic stirrer to facilitate protein solubilization before centrifuged (Allegra 64R Centrifuge, Beckman Coulter Inc., USA) at 10,000 $\times g$ for 30 mins. The supernatant containing the dissolved protein was collected and further filtered using filter paper (Whatman No. 4) to remove any insoluble particles. The filtered supernatant was then acidified to pH 3, 4 and 4.5 to precipitate the dissolved protein. The protein precipitate was recovered by centrifugation and washed with Milli-Q water $(3 \times 50 \mathrm{~mL})$ before resuspended in Milli-Q water at $\mathrm{pH}$ 7.0. The mixture was stirred for 10 mins to solubilize the protein. This protein solution was lyophilized using a freeze dryer (Scanvac CoolSafe Touch 110-4, Labogene, France) and the protein powders obtained were collected. The freezedried chia protein isolated (CI) was packed in an airtight container and stored at $4{ }^{\circ} \mathrm{C}$ until further analysis.

\subsection{Protein quantification}

Protein concentration was determined using Biorad dye reagent (Bio-Rad, Richmon, USA) according to Bradford (1976). A volume of $30 \mu \mathrm{L}$ of each sample was added to $1 \mathrm{~mL}$ of the reagent, and the mixture was reposed for 5 mins before determined the absorbance using a spectrophotometer (UV-160A, Shimadzu, Kyoto, Japan) at $595 \mathrm{~nm}$. A bovine serum albumin (BSA) standard curve was prepared with a $2 \mathrm{mg} / \mathrm{mL}$ stock solution of bovine serum albumin (BSA).

\subsection{Enzymatic hydrolysis}

Chia protein hydrolysate $(\mathrm{CH})$ were prepared via enzymatic hydrolysis by Alcalase ${ }^{\circledR}$ and papain enzyme at a different time of hydrolysis $(15,30,60,120$ and 180 mins) according to the method reported by Chatterjee et al. (2015) with some modifications. The CI was soaked 
in distilled water, and the suspension was incubated with Alcalase ${ }^{\circledR}\left(1: 100 \mathrm{w} / \mathrm{w}, \mathrm{pH} 8,60^{\circ} \mathrm{C}\right)$ or papain $(1: 100 \mathrm{w} /$ $\mathrm{w}, \mathrm{pH} 7,60^{\circ} \mathrm{C}$ ) before heated at $90^{\circ} \mathrm{C}$ for 5 mins for enzyme deactivation. All the $\mathrm{CH}$ samples were filtered with filter paper (Whatman No. 4), and the filtrates were lyophilized using a freeze dryer (Scanvac CoolSafe Touch 110-4, Labogene, France) for further analysis.

\subsection{Degree of hydrolysis}

The effect of hydrolysis time on the degree of hydrolysis $(\mathrm{DH})$ was determined using the trichloroacetic acid (TCA) method with slight modification (Klompong et al., 2007). At the end of each hydrolysis time, an aliquot of $10 \mathrm{~mL}$ of the aqueous suspension of enzymetreated fractions was added to $10 \mathrm{~mL}$ of $20 \%$ trichloroacetic acid (TCA) to obtain 10\% TCA-soluble nitrogen and 10\% TCA-insoluble nitrogen and then centrifuged at $15,770 \times g$ for 15 mins at $4^{\circ} \mathrm{C}$. The supernatant was decanted and analyzed for soluble nitrogen content $(\mathrm{N})$ using the Kjeldahl method (Kjeltec TM 2100, Foss, Denmark). The percentage of DH is expressed as follows.

$$
\mathrm{DH}(\%)=\frac{\text { Soluble } \mathrm{N} \text { in } \mathrm{TCA} 10 \%(\mathrm{w} / \mathrm{v})}{\text { Total } \mathrm{N} \text { in the sample }} \times 100
$$

\subsection{Peptide content}

A rapid, sensitive and convenient o-phthaldialdehyde -(OPA-) based spectroscopic assay with some modification was performed to measure proteolysis of CH in a buffered solution (Church et al., 1983). A fresh OPA solution was prepared as follows: a volume of 25 $\mathrm{mL}$ sodium tetraborate solution $(100 \mathrm{mmol} / \mathrm{L})$ was mixed with $2.5 \mathrm{~mL}$ of $20 \%$ (w/v) sodium dodecyl sulfate solution, $40 \mathrm{mg}$ of OPA solution (dissolved in $1 \mathrm{~mL}$ of methanol) and $100 \mu \mathrm{L}$ of $\beta$-mercaptoethanol. The volume was adjusted to $50 \mathrm{~mL}$ with deionized water. The reagent was then placed in a vial covered with aluminium foil to protect it from light. The amount of 50 $\mu \mathrm{L}$ of each $\mathrm{CH}$ was mixed with $2 \mathrm{~mL}$ of OPA reagent and incubated for 2 mins at ambient temperature. The absorbance at $340 \mathrm{~nm}$ was measured with the spectrophotometer (UV-160A, Shimadzu, Kyoto, Japan). Casein tryptone in phosphate buffer $\mathrm{pH}$ 7.4) was used as a standard to quantify the peptide content.

\subsection{Protein solubility}

The soluble protein component of $\mathrm{CH}$ was determined according to the method of Bradford (1976) based on the observation that the maximum absorbance for an acidic solution of Coomassie Brilliant Blue G-250 (in the dye reagent) shift from $465 \mathrm{~nm}$ to $595 \mathrm{~nm}$ when binding to the protein occurs. The dye reagent was prepared by diluting 1 part of concentrated Bio-rad dye reagent (Bio-Rad, Richmon, USA) with 4 parts of distilled water and filtered through a Whatman No. 4 filter paper to remove particulates. An aliquot of $100 \mu \mathrm{L}$ sample was added to $5 \mathrm{~mL}$ diluted dye reagent and allowed to stand for 5 mins at room temperature. The blue protein-dye form was being measured at $595 \mathrm{~nm}$ using a spectrophotometer (UV-160A, Shimadzu, Kyoto, Japan). The soluble protein content was quantified using bovine serum albumin, BSA.

\subsection{Antioxidant activities}

\subsubsection{DPPH radical scavenging assay}

The DPPH scavenging activity of $\mathrm{CH}$ was measured using the method described by Ahn et al. (2014) with a slight modification. Briefly, a $70 \mu \mathrm{L}$ of $\mathrm{CH}$ was mixed with $70 \mu \mathrm{L}$ of DPPH solution $(150 \mu \mathrm{M}$ in $\mathrm{MeOH})$ followed by standing at room temperature for $30 \mathrm{~min}$ in the dark. The absorbance was measured by a microplate reader (Tecan GENios, Austria $\mathrm{GmbH}$, Austria) at 517 $\mathrm{nm}$. The DPPH radical scavenging activity was expressed by the ascorbic acid equivalent (AAE) using an ascorbic acid standard curve $(10-50 \mu \mathrm{M})$.

DPPH radical scavenging activity $=\frac{\text { (Absorbance control }- \text { Absorbance sample) }}{\text { Absorbance control }}$

\subsubsection{ABTS radical scavenging assay}

The ABTS radical stock solution was prepared according to the method described by Ahn et al. (2014), and the working solution (absorbance with 1.5 at 414 $\mathrm{nm})$ was prepared by dilution). A $50 \mu \mathrm{L}$ of sample and $150 \mu \mathrm{L}$ of ABTS+ were mixed, stand for $10 \mathrm{mins}$, and the absorbance was determined by a microplate reader (Tecan GENios, Austria GmbH, Austria) at $414 \mathrm{~nm}$. The scavenging activity was expressed by $\mu \mathrm{M}$ Trolox equivalent (TE) using a Trolox standard curve (10-50 $\mu \mathrm{M})$.

ABTS radical scavenging activity $=\frac{\text { Absorbance control }- \text { Absorbance sample }}{\text { Absorbance control }}$

\subsubsection{Ferric reducing antioxidant power (FRAP) assay}

The procedure described by Guo et al. (2003) was followed to determine the FRAP activity of the CHbased on the principle reduction of a ferric-tripyridyltriazine complex to its ferrous, colored form in the presence of antioxidants. Briefly, the FRAP reagent contained: 2.5 $\mathrm{mL}$ of $10 \mathrm{mmol} / \mathrm{L}$ TPTZ solution in $40 \mathrm{mmol} / \mathrm{L} \mathrm{HCl}, 2.5$ $\mathrm{mL}$ of $20 \mathrm{mmol} / \mathrm{L} \mathrm{FeCl}_{3}$ and $25 \mathrm{~mL}$ of $0.3 \mathrm{~mol} / \mathrm{L}$ acetate buffer ( $\mathrm{pH}$ 3.6) was prepared freshly. An aliquot of 40 $\mu \mathrm{L}$ of $\mathrm{CH}$ sample was mixed with $0.2 \mathrm{~mL}$ distilled water and $1.8 \mathrm{~mL}$ FRAP reagent. The absorbance of the reaction mixture was spectrophotometrically measured at $593 \mathrm{~nm}$ after incubation at $37^{\circ} \mathrm{C}$ for 10 mins using a spectrophotometer (UV-160A, Shimadzu, Kyoto, Japan). 
The $\mathrm{FeSO}_{4}$ was used as the standard solution. The result was expressed as $\mu \mathrm{M} \mathrm{FeSO}_{4} .7 \mathrm{H}_{2} \mathrm{O}$ equivalent.

\subsection{Amino acid profile}

The amino acid composition of $\mathrm{CH}$ was measured according to Ghassem et al. (2014). The $\mathrm{CH}$ samples were mixed with $6 \mathrm{M}$ hydrochloric acid at $110^{\circ} \mathrm{C}$ for 24 hrs to hydrolyze the protein. The internal standard aaminobutyric acid was added to the hydrolyzed samples and filtered with a $0.2 \mathrm{~mm}$ cellulose acetate membrane filter (Whatman No. 1). The derivations of the amino acids were performed at $55^{\circ} \mathrm{C}$ for 10 mins in a heating block. The separations of the amino acids were performed using a C18 AccQ-Tag amino acid analysis column (3.9 x $150 \mathrm{~mm}$, Waters, USA) with the temperature-controlled at $37^{\circ} \mathrm{C}$ and a flow rate set at 1 $\mathrm{mL} / \mathrm{min}$. The UV detector was operated at $248 \mathrm{~nm}$ (for peak identification), and the excitation and emission wavelength for the fluorescence detector was 250 and $395 \mathrm{~nm}$ (for amino acid quantification), respectively. The number of amino acids was calculated, based on the peak area in comparison with that of the standard. Alkaline hydrolysis was done for determination of Tryptophan level.

\subsection{Statistical analysis}

The analyses were conducted in triplicate. The oneway and two-way analysis of variance (ANOVA) was performed, and the means were compared using Duncan's multiple range test. The data were expressed as the mean \pm standard deviation. The significance value $(p<0.05)$ between samples was determined using Statistical Analysis Software (SAS) 9.4.

\section{Results and discussion}

\subsection{The protein content of chia protein isolated (CI)}

Before undergoing the process of enzymatic hydrolysis, the chia protein was first being isolated from the chia flour using the alkaline extraction and isoelectric point precipitation method. This method was an efficient method to allow protein separation (Pedroche et al., 2004). Figure 1 summarizes the protein content of chia protein isolated $(\mathrm{CI})$ at different alkaline extraction and isoelectric precipitation $\mathrm{pH}$. The protein content of CI was varied between $7.35 \%$ to $17.22 \%$. These relatively low yields could be related to the native content, and biochemical characteristics of the proteins present in chia flour. According to the previous report, the protein content of defatted chia flour is between $18 \%$ to $27 \%$ (da Silva et al., 2017; Cardenas et al., 2018; HernandezDomingues et al., 2019). Based on the result, the highest protein content was obtained at the high extraction $\mathrm{pH}$ $(\mathrm{pH} 12,3.5)$ with the value of $17.22 \%$, while the lowest protein content was recorded by the lowest extraction $\mathrm{pH}$ $(\mathrm{pH} 10,4.5)$ with the value of $7.35 \%$. Alkali might aid protein extraction by increasing the protein solubility. Generally, protein in DCF was not soluble. The solubility of these proteins can be enhanced with the increase of $\mathrm{pH}$ by adding alkali. The alkalization of the medium by adding $\mathrm{NaOH}$ will cause rupture of the disulphide bond, thus improving the protein solubility (Damodaran, 1996). The previous report by Buning et al., (2009) also shown the similar trend where there was a significant increase in protein recovery of cottonseed protein isolates in the more alkaline extraction medium (pH 12.5) up to $70 \%$. However, the result from Figure 1 showed that the $\mathrm{pH}$ effect on isoelectric precipitation did not exhibit a characteristic pattern within treatments, suggesting no significant correlation between the protein concentrations in relation to the isoelectric precipitation. This result contradicted the previous report by Vilg and Undeland (2017), and Liu et al. (2013) stated that the isoelectric precipitate $\mathrm{pH}$ gives the significant effect to the protein recovery of brown seaweed and wheat germ sample, respectively.

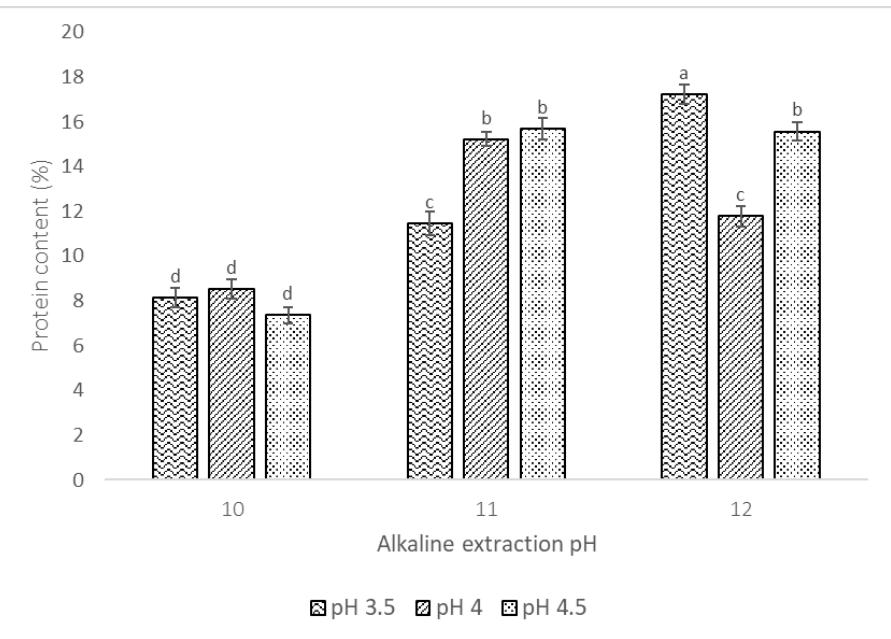

Figure 1 The protein quantification of chia protein isolates (CI) at different alkaline extraction $\mathrm{pH}$ and isoelectric precipitation $\mathrm{pH}$. Different letters on the bars indicate statistical significant difference $(\mathrm{p}<0.05)$ of the protein content $(\%)$.

3.2 The degree of hydrolysis (DH), protein solubility and peptide content of the chia protein hydrolysates $(\mathrm{CH})$

The highest protein content of CI was selected for further enzymatic hydrolysis. The enzymatic hydrolysis of CI was carried out to obtain the degree of hydrolysis (DH) at which was biologically active. Table 1 demonstrated the effect of hydrolysis time on the $\mathrm{DH}$, protein solubility and peptide content of chia protein hydrolysates $(\mathrm{CH})$ using two different proteases: Alcalase ${ }^{\circledR}$ and papain. The DH was influenced by the hydrolysis reaction period and the ability of the proteases to carry out the proteolysis.

As shown in Table 1, a rapid increase in DH occurs 
Table 1. The degree of hydrolysis, protein solubility and peptide content of chia protein hydrolysates at different time of hydrolysis

\begin{tabular}{|c|c|c|c|c|}
\hline Samples & $\begin{array}{c}\text { Time of Hydrolysis } \\
\text { (min) }\end{array}$ & $\begin{array}{c}\text { Degree of Hydrolysis } \\
(\%)\end{array}$ & $\begin{array}{c}\text { Protein solubility } \\
(\mu \mathrm{g} / \mathrm{g})\end{array}$ & $\begin{array}{l}\text { Peptide content } \\
(\mu \mathrm{g} / \mathrm{g})\end{array}$ \\
\hline Defatted Chia Flour (DCF) & - & - & $2.46 \pm 0.19^{\mathrm{I}}$ & $7.12 \pm 0.41^{\mathrm{H}}$ \\
\hline Chia Protein Isolated (CI) & - & - & $19.03 \pm 0.22^{\mathrm{H}}$ & $27.62 \pm 0.64^{\mathrm{G}}$ \\
\hline \multirow{5}{*}{$\begin{array}{l}\text { Chia hydrolysates hydrolyzed using Alcalase } \AA \\
\text { (Alcalase }(-\mathrm{CH})\end{array}$} & 15 & $16.28 \pm 0.45^{\mathrm{G}}$ & $45.39 \pm 0.84^{\mathrm{F}}$ & $59.71 \pm 1.02^{\mathrm{E}}$ \\
\hline & 30 & $32.68 \pm 0.32^{\mathrm{D}}$ & $68.01 \pm 0.78^{C}$ & $90.19 \pm 0.76^{\mathrm{C}}$ \\
\hline & 60 & $47.09 \pm 0.86^{\mathrm{A}}$ & $83.71 \pm 1.06^{\mathrm{A}}$ & $104.46 \pm 0.58^{\mathrm{A}}$ \\
\hline & 120 & $46.83 \pm 1.22^{\mathrm{A}}$ & $83.27 \pm 0.88^{\mathrm{A}}$ & $104.11 \pm 0.36^{\mathrm{A}}$ \\
\hline & 180 & $45.60 \pm 1.10^{\mathrm{B}}$ & $79.91 \pm 0.47^{\mathrm{B}}$ & $103.65 \pm 1.29^{\mathrm{A}}$ \\
\hline \multirow{5}{*}{$\begin{array}{l}\text { Chia hydrolysates hydrolyzed using papain } \\
\text { (Papain-CH) }\end{array}$} & 15 & $10.22 \pm 0.71^{\mathrm{H}}$ & $39.21 \pm 0.41^{\mathrm{G}}$ & $51.43 \pm 0.89^{\mathrm{F}}$ \\
\hline & 30 & $22.52 \pm 0.69^{\mathrm{F}}$ & $59.90 \pm 0.99^{\mathrm{E}}$ & $69.98 \pm 0.76^{\mathrm{D}}$ \\
\hline & 60 & $44.29 \pm 1.01^{\mathrm{B}}$ & $79.98 \pm 0.55^{\mathrm{B}}$ & $95.72 \pm 0.50^{\mathrm{B}}$ \\
\hline & 120 & $31.79 \pm 0.42^{\mathrm{E}}$ & $79.25 \pm 1.02^{\mathrm{B}}$ & $89.70 \pm 0.69^{C}$ \\
\hline & 180 & $39.02 \pm 0.91 \mathrm{C}$ & $65.22 \pm 0.60^{\mathrm{D}}$ & $89.92 \pm 0.56^{\mathrm{C}}$ \\
\hline
\end{tabular}

Values shown are the mean \pm standard deviation of three replicates. Values in the same column without a common superscript letter are significantly different $(\mathrm{p}<0.05)$

during the initial phase of hydrolysis. However, the proteolysis rate of Alcalase ${ }^{\circledR}-\mathrm{CH}$ tends to enter the plateau phase after 60 mins of hydrolysis and become decreases after 120 mins of hydrolysis. It was believed that at the initial stage of hydrolysis, the concentration of substrate and the enzyme activity were relatively higher, leading to a higher rate of bond cleavage and proteolysis. However, as the hydrolysis process continued until reached the reaction equilibrium, the rate of reaction become decreased (Zhang et al., 2012). This result indicates that the DH level is not solely affected by the length of hydrolysis. Several hypotheses from the previous study have explained this trend included a decrease in the concentration of peptide bond (Guerard et al., 2001), thermal inactivation of the enzyme (Demirhan et al., 2011a) and enzyme inhibition by hydrolysis products (Demirhan et al., 2011b). According to Demirhan et al. (2011b), the enzyme catalyst can occur in the reverse reaction. As the hydrolysis time increases, there is an accumulation of hydrolysis product, resulting in the reverse reactions and leads the enzymes to produce the substrate again, and consequently decrease the $\mathrm{DH}$ level. The highest $(\mathrm{p}<0.05) \mathrm{DH}$ was recorded by the Alcalase ${ }^{\circledR}-\mathrm{CH}(47.09 \%, 60$ mins). For Papain- $\mathrm{CH}$, the highest DH was recorded at 60 mins of hydrolysis with the value of $44.29 \%$, a $2.8 \%$ lower $(\mathrm{p}<0.05)$ compared to the Alcalase ${ }^{\circledR}-\mathrm{CH}$. This result shows that the proteolysis reactions of breaking the CI to smaller peptides chains performed faster and more efficient with Alcalase ${ }^{\circledR}$ as catalyst compared to papain. The similar result was found previously by Li et al. (2015) on Camilla oleifera sample, where the DH of the sample that was hydrolyzed using Alcalase ${ }^{\circledR}$ showed significantly higher $\mathrm{DH}$ compared to papain with the value of $31.25 \%$ and $22.13 \%$, respectively. Alcalase ${ }^{\circledR}$ is an endopeptidase enzyme, capable of hydrolyzing protein with a broad spectrum of peptides bond, especially those with large charge-free residues (Hrckova et al., 2002). Besides the $\mathrm{DH}$, the specific and unique enzyme active site is the other most significant factor affecting the resulting bioactivities mainly antioxidant. Therefore, all $\mathrm{CH}$ samples from both Alcalase $\AA$ and papain treatment were further analyzed for antioxidant analysis.

Protein solubility is a key property of food proteins, and it is dependent on the distribution of hydrophobic and hydrophilic amino acids on the protein surface, and the thermodynamic interactions between proteins and water. The determination protein solubility using Bradford assay (Bradford, 1976) involved the binding of Coomassie Brilliant Blue G-25 dye to $\mathrm{CH}$ that causes a shift in the absorption maximum of the dye from $465 \mathrm{~nm}$ (protonated red cationic form) to $595 \mathrm{~nm}$ (stable unprotonated blue) (Reisner et al., 1975). From Table 1, the value of protein solubility was directly proportional to the DH. According to Linares et al. (2000), the enzymatic hydrolysis process produced soluble peptides with both hydrophilic and hydrophobic properties, where the proportion of both are dependent on the DH levels. The enzyme reactions cause the secondary and tertiary structure of the protein to be revealed, which in turn favours the reaction between hydrophobic groups and increases the protein solubility (Nurfatin et al., 2014). The highest $(\mathrm{p}<0.05)$ protein solubility and peptide content were demonstrated by the Alcalase ${ }^{\circledR}-\mathrm{CH}$ at 60 mins of hydrolysis with the values of $83.71 \mu \mathrm{g} / \mathrm{g}$ and $104.46 \mu \mathrm{g} / \mathrm{g}$, respectively. This result indicated that, as the DH increased, the protein solubility and peptide content of $\mathrm{CH}$ also increased. The similar result was obtained by Morais et al. (2013) and Segura-Campos et al. (2012) with the sample of whey and Vigna unguiculate protein hydrolysates, respectively have 
reported that the increase of the protein solubility and peptide contents were directly proportional with the increase of $\mathrm{DH}$.

\subsection{The antioxidant activities of chia protein hydrolysates $(\mathrm{CH})$}

\subsubsection{DPPH radical scavenging activity}

The DPPH radical scavenging assay has been widely used to evaluate radical scavenging activity of food extract because it is more stable than the conventional natural radicals (Chandrasekara and Shahidi, 2011). The assay is based on the reduction of methanolic DPPH radical solution at $517 \mathrm{~nm}$ in the presence of the hydrogen donating antioxidant, due to the formation of the non-radical DPPH-H by the reaction (Dong et al., 2015). The hydrogen-donating substance would scavenge the DPPH radical, and subsequently, the absorbance is reduced (Shimada, 1992). Based on this principle, the scavenging ability of $\mathrm{CH}$ hydrolyzed using Alcalase ${ }^{\circledR}$ and papain at different times of hydrolysis on the DPPH radicals were measured. The results are reported as the ascorbic acid equivalent (AAE) and are shown in Table 2. The DCF demonstrated the lowest $(p<0.05)$ DPPH radical scavenging with the value of $4.45 \mu \mathrm{M}$ AAE followed by the CI with the value of 9.19 $\mu \mathrm{M}$ AAE. This result showed that the protein from chia was naturally contained large molecules with limited accessibility of functional chains (R-groups) with reactive species and electron-dense peptide bonds. Nevertheless, the free radical scavenging capacity was significantly enhanced after enzymatic hydrolysis. The DPPH free radical scavenging activities of both Alcalase $\AA$ and papain treatment were increased by the increasing of hydrolysis period up to 60 mins, with the highest values of $35.46 \mu \mathrm{M}$ AAE and $33.09 \mu \mathrm{M}$ AAE,

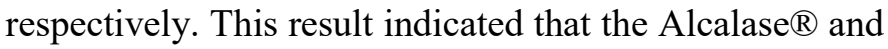
papain catalyst was successfully released antioxidant peptides that are inactive when they are encrypted in the intact protein. According to Shahi et al. (2020), the antioxidant activity of the samples potentially enhanced by increasing the hydrolysis time following increasing the degree of hydrolysis and releasing more hydrophobic and active peptides and amino acids. The enzymatic hydrolysis releases more hydrophobic and shorter active peptides that highly responses to DPPH radicals, thus these compound have a higher capacity to be promptly accessible and inhibit the free radicals and assigned as an excellent antioxidant (Je et al., 2005; Kamdem and Tsopmo, 2019).

However, the extension of the hydrolysis time of both enzymes used represented a decrease in scavenging activity. The decreased of the scavenging activities after 60 mins of hydrolysis can be explained by the prolongation of hydrolysis process caused completed hydrolysis of peptides, leading to the released and high availability of free hydrophilic amino acids that are no longer active as an antioxidant (You et al., 2009). Besides that, the polarization also potentially reduced the scavenging capability of amino acids to DPPH radical (Zhao et al., 2010). The previous study by $\mathrm{Li}$ et al. (2015) and Shahi et al. (2020) on a sample of Camilla oleifera and Bunium persicum Bioss press cake, respectively showed that the proteolysis by Alcalase $\AA$, papain and pancreatin resulted in shorter peptides and generated potential antioxidative hydrolysates up to a

Table 2. The antioxidant activities of chia protein hydrolysates hydrolyzed using different proteases at the different time of hydrolysis

\begin{tabular}{|c|c|c|c|c|}
\hline Samples & $\begin{array}{c}\text { Time of incubation } \\
(\mathrm{hr})\end{array}$ & $\begin{array}{c}\text { DPPH Radical Scavenging } \\
\text { Activity } \\
\text { ( } \mu \mathrm{M} \text { ascorbic acid equivalent) }\end{array}$ & $\begin{array}{c}\text { ABTS Radical } \\
\text { Scavenging Activity } \\
\text { ( } \mu \mathrm{M} \text { Trolox equivalent) }\end{array}$ & $\begin{array}{c}\text { FRAP } \\
\begin{array}{c}\mu \mathrm{M} \mathrm{FeSO}_{4} \cdot 7 \mathrm{H}_{2} \mathrm{O} \\
\text { equivalent })\end{array}\end{array}$ \\
\hline Defatted Chia Flour (DCF) & - & $4.45 \pm 0.24^{\mathrm{J}}$ & $3.79 \pm 0.16^{\mathrm{I}}$ & $0.26 \pm 0.22^{\mathrm{J}}$ \\
\hline Chia Protein Isolated (CI) & - & $9.19 \pm 0.27^{\mathrm{I}}$ & $8.45 \pm 0.16^{\mathrm{H}}$ & $6.75 \pm 0.28^{\mathrm{I}}$ \\
\hline $\begin{array}{l}\text { Chia hydrolysates } \\
\text { hydrolyzed using } \\
\text { Alcalase } \mathbb{}\end{array}$ & 15 & $19.96 \pm 0.32^{\mathrm{G}}$ & $20.08 \pm 0.27^{\mathrm{F}}$ & $8.53 \pm 0.41^{\mathrm{H}}$ \\
\hline (Alcalase ${ }^{\circledR}-\mathrm{CH}$ ) & 30 & $27.21 \pm 0.39^{\mathrm{E}}$ & $25.01 \pm 0.27^{\mathrm{E}}$ & $14.07 \pm 0.31^{\mathrm{F}}$ \\
\hline \multirow{8}{*}{$\begin{array}{l}\text { Chia hydrolysates } \\
\text { hydrolyzed using papain } \\
\text { (Papain-CH) }\end{array}$} & 60 & $35.46 \pm 0.32^{\mathrm{A}}$ & $34.45 \pm 0.31^{\mathrm{A}}$ & $23.11 \pm 0.31^{\mathrm{A}}$ \\
\hline & 120 & $33.42 \pm 0.27^{\mathrm{B}}$ & $33.76 \pm 0.16^{\mathrm{B}}$ & $22.89 \pm 0.17^{\mathrm{A}}$ \\
\hline & 180 & $33.18 \pm 0.46^{\mathrm{B}}$ & $29.35 \pm 0.21^{\mathrm{C}}$ & $21.26 \pm 0.18^{\mathrm{B}}$ \\
\hline & 15 & $15.42 \pm 0.52^{\mathrm{H}}$ & $18.51 \pm 0.39^{\mathrm{G}}$ & $8.49 \pm 0.15^{\mathrm{H}}$ \\
\hline & 30 & $22.90 \pm 0.1^{\mathrm{F}}$ & $20.03 \pm 0.27^{\mathrm{F}}$ & $10.51 \pm 0.38^{\mathrm{G}}$ \\
\hline & 60 & $33.09 \pm 0.41^{\mathrm{B}}$ & $29.39 \pm 0.28^{\mathrm{C}}$ & $20.16 \pm 0.25^{\mathrm{C}}$ \\
\hline & 120 & $32.01 \pm 0.59^{\mathrm{C}}$ & $29.02 \pm 0.17^{\mathrm{D}}$ & $17.99 \pm 0.21^{\mathrm{D}}$ \\
\hline & 180 & $30.98 \pm 0.61^{\mathrm{D}}$ & $29.05 \pm 0.27^{\mathrm{D}}$ & $16.69 \pm 0.25^{\mathrm{E}}$ \\
\hline
\end{tabular}

Values shown are the mean \pm standard deviation of three replicates. Values in the same column without a common superscript letter are significantly different $(\mathrm{p}<0.05)$ 
certain period and yet decreased with the prolongation of the hydrolysis process. $\mathrm{CH}$ hydrolyzed using Alcalase ${ }^{\circledR}$ showed significantly higher activity compared to papain. Alcalase ${ }^{\circledR}$ is an alkaline protease used to produce protein hydrolysates with better functional and nutritional characteristic than the original protein. According to Torucco-Uco et al. (2009), Alcalase ${ }^{\circledR}$ exhibited the subtilisin serine group in its active site, which has endopeptidase activity. Alcalase ${ }^{\circledR}$ hydrolyzed peptides with broad specificity, releasing peptides with antioxidant potential hydrophobic amino acids. Li et al. (2015) also reported that Alcalase $\AA$ exhibited higher DPPH radical scavenging ability on the Camellia sinesis $L$. seed cake compared to papain with the EC50 values of 1.65 and 2.74 , respectively.

\subsubsection{ABTS radical scavenging activity}

The antioxidative potential, cationic and watersoluble radical inhibitory ability of ABTS is dependent on the degree of hydrolysis and the amino acid composition of the peptide chains. Whereas, the sequences of the peptides are specifically dependent on the mechanism of actions of each protease enzyme (Sarmadi and Ismail 2010; Kamdem and Tsopmo, 2019). Table 2 exhibits the effect of different type of enzymes and time of hydrolysis on the ABTS scavenging activities reported as Trolox equivalent (TE). All the $\mathrm{CH}$ analyzed exhibited a higher radical scavenging ability compared to the DCF and CI. According to Table 2, the DCF and CI showed the lower ABTS radical scavenging potential, both with values of $3.79 \mu \mathrm{M}$ TE and $8.45 \mu \mathrm{M}$ TE, respectively. However, there were significant increases in ABTS radical scavenging capabilities with the increasing of hydrolysis time up to $60 \mathrm{mins}$ for both Alcalase ${ }^{\circledR}$ and papain enzyme with values of $34.45 \mu \mathrm{M}$ TE and $29.39 \mu \mathrm{M}$ TE, respectively. During the enzymatic treatment, the release of electron and hydrogen donating properties of the active peptides from the intact protein might have led to an increase in ABTS scavenging activity (Pihlanto et al., 2008). These peptides could potentially react with the free radicals and convert them to more stable products and in turn stop the radical chain reaction (Pazinatto et al., 2013). However, after 60 mins of hydrolysis period, the radical scavenging activities tend to decrease $(p<0.05)$. This happens because at this point most of the proteins or peptides are further degraded into inactive free amino acids, whereby these free amino acids are no longer function as an antioxidant (Samaranayaka and Li-Chan, 2011). According to the result reported by Tironi et al. (2010), the antioxidant capacity of peptides can decrease or completely lost after being change into free amino acids.
Among them, Alcalase ${ }^{\circledR}$ hydrolysate was the most potent for ABTS radical scavenging because it showed higher $(p<0.05)$ activities during all the hydrolysis period. The ability of Alcalase ${ }^{\circledR}$ as a good radical scavenger is due to the nature of the Alcalase ${ }^{\circledR}$ itself as an endopeptidase which has a broad range of specificity towards the peptide bond especially residues without big charges (Rusnakova et al. 2002). The higher ABTS scavenging activity of the Alcalase ${ }^{\circledR}$ hydrolysates in comparison to other enzymes is confirmed in the previous literature. Alcalase ${ }^{\circledR}$ released peptides from flaxseed protein capable of scavenging ABTS more effectively than those obtained with papain and trypsin (Karamac et al., 2016). Ye et al. (2018) also found that the protein hydrolysates of carrot seed hydrolysate demonstrated the highest ABTS radical scavenging activities compared to those produced with papain, trypsin and neutrase.

\subsubsection{Ferric reducing antioxidant power (FRAP)}

The FRAP assay is a method that directly measures antioxidant in a sample and usually applied to evaluate the natural antioxidant ability to donate electron (Dorman et al., 2003). It is deemed as a suitable assessment for total antioxidants in plants because the only compound that FRAP does not react with are thiols (Pyne et al., 2013). The method is based on the reduction of colourless ferric tripyridyltriazine $\left(\mathrm{Fe}^{3+}-\mathrm{TPTZ}\right.$ complex) to blue coloured ferrous tripyridyltriazine $\left(\mathrm{Fe}^{2+}\right.$ -TPTZ complex) formed by the action of breaking radical change through donating a hydrogen atom (Rajurkar and Hande, 2011). The FRAP reducing power activity of $\mathrm{CH}$ hydrolyzed by Alcalase ${ }^{\circledR}$ and papain was demonstrated in Table 2. Among the samples, the DCF showed the lowest reducing ability with a value of 0.26 $\mu \mathrm{M} \mathrm{FeSO}{ }_{4} .7 \mathrm{H}_{2} \mathrm{O}$ equivalent. The unhydrolyzed $\mathrm{CI}$ also demonstrated a low reducing power with a value of 6.75 $\mu \mathrm{M} \mathrm{FeSO} 4.7 \mathrm{H}_{2} \mathrm{O}$ equivalent. According to Xiao et al. (2014), the enzymatic hydrolysis caused an increase in free amino acids, and peptide fragments provide an additional source of electron and protons to maintain a high redox potential. After enzymatic hydrolysis by both Alcalase ${ }^{\circledR}$ and papain, the reducing power abilities significantly increased. The highest reducing power showed by Alcalase ${ }^{\circledR}-\mathrm{CH}$ and Papain- $\mathrm{CH}$ were shown at 60 mins of hydrolysis with values of 23.11 and 20.16 $\mu \mathrm{M} \mathrm{FeSO}{ }_{4} \cdot 7 \mathrm{H}_{2} \mathrm{O}$ equivalent, respectively. In the other words, the FRAP reducing power of the $\mathrm{CH}$ obtained using Alcalase ${ }^{\circledR}$ and papain were about 3-folds higher than those of the non-hydrolyzed CI. Prolongation of hydrolysis resulted in the decreased of reducing power ability. According to Sbroggio et al., 2016), extensive hydrolysis would lead to the formation of shorter peptides (tri- and dipeptides) and free amino acids. 
Comparing these two enzymes, Alcalase ${ }^{\circledR}$ seen to have a higher capacity to release a high amount of hydrogen or electron-donating amino acid responsible for $\mathrm{Fe}^{3+}$ reduction compared to papain. The high ability of Alcalase ${ }^{\circledR}-\mathrm{CH}$ is associated with the exposure of electron-dense amino acid side chain group (Thamnarathip et al., 2016), attributed to the specific peptide or amino acid composition produced by the enzyme (Wu et al. 2003). The values of FRAP reducing power of $\mathrm{CH}$ were comparable than those obtained for horse gram hydrolysates hydrolyzed with Alcalase ${ }^{\circledR}$ (Bashkar et al., 2019) and rice bran protein digested with the pepsin-trypsin system (Phongthai et al., 2018).

\subsection{Amino acid profile}

The $\mathrm{CH}$ samples of each enzyme with the highest antioxidant activities were selected for amino acid profiling. The antioxidant properties of peptides are greatly influenced by the amino acid composition of the peptide (Malomo et al., 2014). The amino acid composition of the DCF, CI, Alcalase ${ }^{\circledR}-\mathrm{CH}$ and Papain$\mathrm{CH}$ were summarised in Table 3. The major amino acids found in $\mathrm{CH}$ were Glu, Arg, Asp, Ser, Phe, Gly and Thr.
The essential amino acids in the Alcalase ${ }^{\circledR}-\mathrm{CH}$ and Papain- $\mathrm{CH}$ were also found in relatively high amounts $(p<0.05)$ with the total percentage of $41.07 \%$ and $38.76 \%$, respectively compared to the DCF $(33.71 \%)$ and CI $(35.48 \%)$. The hydrophobic amino acids in the $\mathrm{CH}$ was significantly higher $(p<0.05)$ compared to the DCF and $\mathrm{CI}$ with the highest was demonstrated by Alcalase ${ }^{\circledR}$ $\mathrm{CH}$ with values of $42.51 \%$ followed by Papain- $\mathrm{CH}$ with the value of $37.25 \%$. The increases of $8.69 \%$ and $3.43 \%$ respectively were due to the increasing values of Ala, Pro, Tyr, Val, Ile and Leu. The highest content of hydrophobic amino acid in $\mathrm{CH}$ has been expected because enzymatic hydrolysis generally exposes more protein chains, which increase the hydrophobicity. The antioxidant peptides could smoothly enter target organs through hydrophobic interactions with membrane lipid bilayers by the aid of their hydrophobicity, where they are able to exert significant capacity of scavenging radicals (Pouzo et al., 2016). The hydrophobic amino acids facilitated interactions with hydrophobic targets, such as the cell membrane, and thereby, enhance the bioavailability (Himaya et al., 2012). The hydrophobic amino acid such as Val and Ile responsible for forming a

Table 3. The amino acid profile of the defatted chia flour (DCF), chia isolated (CI) and chia hydrolysates $(\mathrm{CH})$

\begin{tabular}{lcccc}
\hline Amino acids & DCF (\%) & CI (\%) & Alcalase ${ }^{\circledR}-\mathrm{CH}(\%)$ & Papain-CH (\%) \\
\hline Asp & $9.72 \pm 0.52^{\mathrm{A}}$ & $9.12 \pm 0.03^{\mathrm{B}}$ & $6.35 \pm 0.03^{\mathrm{C}}$ & $9.40 \pm 0.35^{\mathrm{BA}}$ \\
Ser & $7.40 \pm 0.22^{\mathrm{A}}$ & $6.86 \pm 0.12^{\mathrm{B}}$ & $6.35 \pm 0.29^{\mathrm{C}}$ & $4.64 \pm 0.06^{\mathrm{D}}$ \\
Glu & $18.46 \pm 0.31^{\mathrm{A}}$ & $18.07 \pm 0.14^{\mathrm{B}}$ & $12.24 \pm 0.95^{\mathrm{D}}$ & $17.13 \pm 0.21^{\mathrm{C}}$ \\
Gly & $5.57 \pm 0.12^{\mathrm{A}}$ & $5.09 \pm 0.17^{\mathrm{B}}$ & $5.12 \pm 0.08^{\mathrm{B}}$ & $4.70 \pm 0.14^{\mathrm{C}}$ \\
His & $3.52 \pm 0.09^{\mathrm{C}}$ & $3.80 \pm 0.04^{\mathrm{B}}$ & $4.93 \pm 0.58^{\mathrm{A}}$ & $3.20 \pm 0.10^{\mathrm{D}}$ \\
Arg & $12.69 \pm 0.05^{\mathrm{A}}$ & $12.00 \pm 0.15^{\mathrm{B}}$ & $11.20 \pm 1.02^{\mathrm{B}}$ & $9.71 \pm 0.26^{\mathrm{C}}$ \\
Thr & $5.43 \pm 0.01^{\mathrm{A}}$ & $4.50 \pm 0.02^{\mathrm{C}}$ & $4.68 \pm 0.01^{\mathrm{B}}$ & $3.55 \pm 0.37^{\mathrm{D}}$ \\
Ala & $3.33 \pm 0.11^{\mathrm{C}}$ & $3.24 \pm 0.02^{\mathrm{C}}$ & $4.08 \pm 0.29^{\mathrm{B}}$ & $4.52 \pm 0.29^{\mathrm{A}}$ \\
Pro & $3.72 \pm 0.14^{\mathrm{D}}$ & $4.09 \pm 0.02^{\mathrm{C}}$ & $4.64 \pm 0.07^{\mathrm{A}}$ & $4.29 \pm 0.05^{\mathrm{B}}$ \\
Tyr & $3.46 \pm 0.24^{\mathrm{C}}$ & $3.70 \pm 0.09^{\mathrm{C}}$ & $5.20 \pm 0.46^{\mathrm{A}}$ & $3.92 \pm 0.19^{\mathrm{B}}$ \\
Val & $4.00 \pm 0.11^{\mathrm{C}}$ & $4.60 \pm 0.08^{\mathrm{B}}$ & $4.97 \pm 0.04^{\mathrm{A}}$ & $4.69 \pm 0.11^{\mathrm{B}}$ \\
Lys & $4.64 \pm 0.08^{\mathrm{A}}$ & $4.39 \pm 0.15^{\mathrm{B}}$ & $2.87 \pm 0.05^{\mathrm{C}}$ & $4.42 \pm 0.10^{\mathrm{B}}$ \\
Ile & $1.69 \pm 0.13^{\mathrm{C}}$ & $1.97 \pm 0.01^{\mathrm{B}}$ & $4.17 \pm 0.40^{\mathrm{A}}$ & $4.02 \pm 0.22^{\mathrm{A}}$ \\
Leu & $4.01 \pm 0.08^{\mathrm{D}}$ & $4.29 \pm 0.02^{\mathrm{C}}$ & $6.92 \pm 0.13^{\mathrm{B}}$ & $7.22 \pm 0.29^{\mathrm{A}}$ \\
Phe & $5.94 \pm 0.11^{\mathrm{C}}$ & $6.63 \pm 0.01^{\mathrm{B}}$ & $7.20 \pm 0.08^{\mathrm{A}}$ & $4.14 \pm 0.35^{\mathrm{D}}$ \\
Cys & $0.88 \pm 0.05^{\mathrm{D}}$ & $0.94 \pm 0.03^{\mathrm{C}}$ & $0.98 \pm 0.03^{\mathrm{B}}$ & $2.93 \pm 0.02^{\mathrm{A}}$ \\
Met & $4.48 \pm 0.01^{\mathrm{B}}$ & $5.29 \pm 0.03^{\mathrm{A}}$ & $5.32 \pm 0.01^{\mathrm{A}}$ & $4.45 \pm 0.11^{\mathrm{B}}$ \\
Trp & $1.05 \pm 0.17^{\mathrm{C}}$ & $1.40 \pm 0.04^{\mathrm{B}}$ & $2.78 \pm 0.31^{\mathrm{A}}$ & $3.07 \pm 0.15^{\mathrm{A}}$ \\
Total amino acid $(\%)$ & 100 & 100 & 100 & 100 \\
Total EAA $\left.{ }^{1} \%\right)$ & $33.71 \pm 0.39^{\mathrm{D}}$ & $35.48 \pm 0.22^{\mathrm{C}}$ & $41.07 \pm 1.11^{\mathrm{A}}$ & $38.76 \pm 0.09^{\mathrm{B}}$ \\
Total AAH $^{2}(\%)$ & $30.63 \pm 0.21^{\mathrm{D}}$ & $33.82 \pm 0.04^{\mathrm{C}}$ & $42.51 \pm 1.32^{\mathrm{A}}$ & $37.25 \pm 0.27^{\mathrm{B}}$ \\
Total $\mathrm{AAR}^{3}$ (\%) & $13.97 \pm 0.38^{\mathrm{C}}$ & $15.54 \pm 0.16^{\mathrm{B}}$ & $20.10 \pm 1.26^{\mathrm{A}}$ & $14.33 \pm 0.51^{\mathrm{C}}$ \\
\hline
\end{tabular}

Values shown are the mean \pm standard deviation of three replicates. Values in the same column without a common superscript letter are significantly different $(\mathrm{p}<0.05)$.

${ }^{1} \mathrm{EAA}=$ Essential amino acid (His, Thr, Val, Lys, Ile, Leu, Phe, Met, Trp)

${ }^{2} \mathrm{HAA}=$ Hydrophobic amino acid (Ala, Val, Met, Ile, Leu, Phe, Pro and Tyr)

${ }^{3} \mathrm{AAR}=$ Aromatic amino acid (Phe, His, Trp and Tyr) 
favourable hydrophobic micro-environment for peptide molecule (Bougatef et al., 2010). The highest hydrophobic amino acid content of the Alcalase ${ }^{\circledR}-\mathrm{CH}$ has supported the result of antioxidant that has been discussed previously. The hydrolysates containing the higher amount of hydrophobic amino acids such as Leu, Ala, Pro and Phe, as well as other amino acid groups such as Tyr, Met and His, has been shown to enhance the potency of antioxidant peptides through proton-donation ability, electron-donation ability, and direct lipid radical scavengers (Sarmadi and Ismail, 2010; Samaranayaka and Li-Chan, 2011). Previous studies have been reported that the high content of hydrophobic amino acids found in the Moringa oleifera protein hydrolysates by Alcalase ${ }^{\circledR}$ with a value of $39.64 \%$ was one of the factors contributing to high antioxidant capabilities of the peptides (Aderinola et al., 2018).

The total percentage of aromatic amino acid in the Alcalase ${ }^{\circledR}-\mathrm{CH}$ samples also increased significantly $(p<0.05)$ after the enzymatic hydrolysis with the increasing value of $4.56 \%$. Aromatic amino acids with large side group such as His and Trp contribute to the antioxidant potency of peptides because they act as hydrogen donors (Nam et al., 2008). According to Sarmadi and Ismail (2010), the aromatic amino acids (Phe, His, Tyr and Trp) are generally known as a positive free radical scavenger which can convert the free radicals to the stable molecules by donating electrons while retaining their stability through resonance structures increasing the radical-scavenging properties of the amino acid residues. This finding also has been supported by Rong et al. (2012) reported that the content of aromatic amino acids (Trp, Phe and Tyr) in the rapeseed protein hydrolysates fraction significantly increased $(\mathrm{p}<0.05)$ to $15.88 \%$ compared to unhydrolyzed sample (13.33\%).

\section{Conclusion}

The results demonstrated that the highest CI was being isolated at the combination of extraction $\mathrm{pH} 12$ and the precipitate $\mathrm{pH}$ 3.5. Two different protease enzymes (Alcalase ${ }^{\circledR}$ and papain) were used for the hydrolysis of CI. The enzymatic hydrolysis using Alcalase ${ }^{\circledR}$ and papain have significantly $(p<0.05)$ increased the $\mathrm{DH}$, protein solubility, peptides content, and subsequently succeeded in enhancing the antioxidant capability of $\mathrm{CH}$. The highest antioxidant activity was demonstrated by Alcalase ${ }^{\circledR}-\mathrm{CH}$ at 60 mins of hydrolysis as determined via DPPH and ABTS radical scavenging assay and FRAP reducing power assay. The higher antioxidant activities were due to the increased of hydrophobic and aromatic amino acids in the $\mathrm{CH}$. This result proved that the enzymatic hydrolysis of $\mathrm{CI}$ using Alcalase ${ }^{\circledR}$ and papain improved the nutritional and antioxidant capabilities compared to unhydrolyzed CI, thus represent a naturally occurring antioxidant ingredient in the production of functional food and nutraceutical appliance with significant health benefits.

\section{Conflict of interest}

The authors declare no conflict of interest.

\section{Acknowledgements}

The authors would like to thank Universiti Kebangsaan Malaysia (UKM) for the provision of Prime Impact Grant (DIP-2018-036) and Research University Grant (GUP-2018-018), Ministry of Education Malaysia for the provision of Fundamental Research Grant Scheme (FRGS/1/2020/STG01/UKM/02/5), Innovation Centre for Confectionery Technology (MANIS) and Faculty of Science and Technology for laboratory facilities.

\section{References}

Aderinola, T.A., Fagbemi, T.N., Anujiugha, V.N., Alashi, A.M. and Aluko, R.E. (2018). Amino acid composition and antioxidant properties of Moringa oleifera seed protein isolate and enzymatic hydrolysates. Heliyon, 4(10), e00877. https:// doi.org/10.1016/j.heliyon.2018.e00877

Ahn, C.-B., Kim, J.-G. and Je, J.-Y. (2014). Purification and antioxidant properties of octapeptide from salmon by-product protein hydrolysate by gastrointestinal digestion. Food Chemistry, 147, 7883. https://doi.org/10.1016/j.foodchem.2013.09.136

Bashkar, B., Ananthanarayan, L. and Jamdar, S.N. (2019) Effect of enzymatic hydrolysis on the functional, antioxidant, and angiotensin I-converting enzyme (ACE) inhibitory properties of whole horse gram flour. Food Science and Biotechnology, 28(1), 43-52. https://doi.org/10.1007/s10068-018-0440-z

Bougatef, A., Nedjar-Arroume, N., Manni, L., Ravallec, R., Barkia, A., Guillochon, D. and Nasri, M. (2010). Purification and identification of novel antioxidant peptides from enzymatic hydrolysates of sardinelle (Sardinella aurita) by-products proteins. Food Chemistry, 118(3), 559-565. https://doi.org/10.1016/ j.foodchem.2009.05.021

Bradford, M.M. (1976). A rapid and sensitive method for the quantitation of microgram quantities of protein utilizing the principle of protein-dye binding. Journal of Analytic Biochemistry, 72(1-2), 248-25. https://doi.org/10.1016/0003-2697(76)90527-3

Buning, Z., Cui, Y., Guoqiang, Y. and Xinming, L. (2009). Alkaline extraction method of Cottonseed 
protein isolate. Modern Applied Science, 3(3), 77-82. https://doi.org/10.5539/mas.v3n3p77

Cardenas, M., Carpio, C., Welbaum, J., Vilcacundo, E. and Carillo, W. (2018). Chia protein concentrate (Salvia Hispanica L.) anti-inflammatory and antioxidant activity. Asian Journal of Pharmaceutical and Clinical Research, 12(2), 382386. ajpcr.2018.v11i2.17225

Chandrasekara, A. and Shahidi, F. (2011). Determination of antioxidant activity in free and hydrolyzed fractions of millet grains and characterization of their phenolic profiles by HPLC-DAD-ESI-MSn. Journal of Functional Foods, 3(3), 144-158. https:// doi.org/10.1016/j.jff.2011.03.007

Chatterjee, R., Dey, T.K., Ghosh, M. and Dhar, P. (2015). Enzymatic modification of sesame seed protein sourced from waste resource for nutraceutical application. Food and Bioproducts Processing, 94, 70-81. https://doi.org/10.1016/ j.fbp.2015.01.007

Church, F.C., Swaisgood, H.E., Porter, D.H. and Catignani, G.L. (1983). Spectrophotometric assay using o-phthaldialdehyde for determination of proteolysis in milk and isolated milk proteins. Journal of Dairy Science, 66, 1219-1227. https:// doi.org/10.3168/jds.S0022-0302(83)81926-2

da Silva, B.P., Anunciacao, P.C., Matyelka, J.C.D.S., Della Lucia, C.M., Martino, H.S.D. and PinheiroSant'Ana, H.M. (2017). Chemical composition of Brazilian chia seeds grown in different places. Food Chemistry, 221, 1709- 1716. https://doi.org/10.1016/ j.foodchem.2016.10.115

Damodaran, S. (1996). Amino acids, peptides, and proteins. In Fennema, O.R. (Ed). Food Chemistry, p. 321-429. New York: Maecel Dekker Inc.

Demirhan, E., Apar, K. and Ozbek, B. (2011a). Sesame cake protein hydrolysis by Alcalase ${ }^{\circledR}$ : effects of process parameters on hydrolysis, solubilization and enzymatic inactivation. Korean Journal of Chemical Engineering, 28, 195-202. https://doi.org/10.1007/ s11814-010-0316-2

Demirhan, E., Apar, D.K. and Ozbek, B. (2011b). A kinetic study on sesame cake protein hydrolysis by Alcalase ${ }^{\circledR}$. Journal of Food Science, 76(1), C64C67. https://doi.org/10.1111/j.17503841.2010.01938.x

Dong, J.W., Xing, Y., Cai, L. and Yu, J. (2015). Reevaluation of ABTS center dot plus Assay for Total Antioxidant Capacity of Natural Products. Natural Product Communication, 10(12), 2169-2172. https:// doi.org/10.1177/1934578X1501001239
Dorman, D., Kahlos, K., Kosar, M. and Holm, Y. (2003). Antioxidant Properties and Composition of Aqueous Extracts from Mentha Species, Hybrids, Varieties, and Cultivars. Journal of Agricultural and Food Chemistry, 51(16), 4563-4569. https:// doi.org/10.1021/jf034108k

Fernández-López, J., Lucas-Gonzalez, R., Viuda-Martos, M., Sayas-Barberá, E. and Pérez-Alvarez, J.A. (2018). Chia oil extraction co-product as a potential new ingredient for the food industry: Chemical, physicochemical, techno-functional and antioxidant properties. Plant Foods for Human Nutrition, 73, 130-136. https://doi.org/10.1007/s11130-018-0670-5

Garcia, M.C., Puchalska, P., Esteve, C. and Marina, M.L. (2013). Vegetable foods: A cheap source of proteins and peptides with antihypertensive, antioxidant, and other less occurrence bioactivities. Talanta, 106, 328 -349. https://doi.org/10.1016/j.talanta.2012.12.041

Ghassem, M., Babji, A.S., Said, M., Mahmoodani, F. and Arihara, K. (2014). Angiotensin I-Converting Enzyme Inhibitory Peptides from Snakehead Fish Sarcoplasmic Protein Hydrolysate. Journal of Food Biochemistry, 38(2), 140-149. https:// doi.org/10.1111/jfbc.12031

Guerard, F., Dufosse, L., Broise, D.D.L. and Binet, A. (2001). Enzymatic hydrolysis of proteins from yellowfin tuna (Thunnus albacares) wastes using Alcalase ${ }^{\circledR}$. Journal of molecular catalysis $B$ : Enzymatic, 11(4-6), 1051-1059. https:// doi.org/10.1016/S1381-1177(00)00031-X

Guo, C., Yang, J., Wei, J., Li, Y., Xu, J. and Jiang, Y. (2003). Antioxidant activities of peel, pulp and seed fractions of common fruits as determined by FRAP assay. Nutrition Research, 23(12), 1719-1726. https://doi.org/10.1016/j.nutres.2003.08.005

Hernandez-Domingues, E.M., Ramirez-Romero, B., Villa-Garcia, M., Mercado-Flores, Y. and AlvarezCervantes, J. (2019.) Antioxidant activity of peptides obtained from reserve proteins of Salvia hispanica $L$. Journal of Microbiology and Biological Sciences, 7 (3), 27-32.

Himaya, S.W., Ryu, B., Ngo, D.H. and Kim, S.K. (2012). Peptide isolated from Japanese flounder skin gelatin protects against cellular oxidative damage. Journal of Agricultural and Food Chemistry, 60, 9112-9119. https://doi.org/10.1021/jf302161m

Hrckova, M., Rusnakova, M. and Zemanovic, J. (2002). Enzymatic hydrolysis of defatted soy flour by three different proteases and their effect on the functional properties of resulting protein hydrolysates. Czech Journal of Food Science, 20(1), 7-14. https:// doi.org/10.17221/3503-CJFS 
Je, J.Y., Park, P.J. and Kim, S.K. (2005). Antioxidant activity of a peptide isolated from Alaska pollack (Theragra chalcogramma) frame protein hydrolysate. Food Research International, 38(1), 45 -50. https://doi.org/10.1016/j.foodres.2004.07.005

Kamdem, J.P. and Tsopmo, A. (2019). Reactivity of peptides within the food matrix. Journal of Food Biochemistry, 43, e12489. https://doi.org/10.1111/ jfbc. 12489

Karamac, M., Kosinska, A. and Kulczyk, A. (2016). Use of different proteases to obtain flaxseed protein hydrolysates with antioxidant activity. International Journal of Molecular Sciences, 17(7), 1027-1040. https://doi.org/10.3390/ijms17071027

Kim, S.W. and Wijesekara, I. (2010). Development and biological activities of marine-derived bioactive peptides: A review. Journal of Functional Food, 2 (1), 1-9. https://doi.org/10.1016/j.jff.2010.01.003

Klompong, V., Benjakul, S., Kantachote, D. and Shahidi, F. (2007). Antioxidative activity and functional properties of protein hydrolysate of yellow stripe trevally (Selaroides leptolepis) as influenced by the degree of hydrolysis and enzyme type. Food Chemistry, 102(4), 1317-1327. https:// doi.org/10.1016/j.foodchem.2006.07.016

Lee, S.H., Qian, Z.J. and Kim, S.K. (2010). A novel angiotensin I-converting enzyme inhibitory peptide from tuna frame protein hydrolysate and its antihypertensive effect in spontaneously hypertensive rats. Food Chemistry, 118(1), 96-102. https://doi.org/10.1016/j.foodchem.2009.04.086

Li, X., Deng, J., Shen, S., Yuan, M., Yang, R. and Ding, C. (2015). Antioxidant activities and functional properties of enzymatic protein hydrolysates from defatted Camellia oleifera seed cake. Journal of Food Science and Technology, 52(9), 5681-5690. https://doi.org/10.1007/s13197-014-1693-z

Linares, E., Larre, C., Lemeste, M. and Popineau, Y. (2000). Emulsifying and foaming properties of gluten hydrolysates with an increasing degree of hydrolysis: Role of soluble and insoluble fractions. Cereal Chemistry, 77(4), 414-420. https:// doi.org/10.1094/CCHEM.2000.77.4.414

Liu, F.R., Chen, Z.X., Wang, L. and Wang, R. (2013). Effects of protein solubilisation and precipitation $\mathrm{pH}$ values on the functional properties of defatted wheat germ protein isolates. International Journal of Food Science and Technology, 48(7), 1490-1497. https:// doi.org/10.1111/ijfs. 12117

Lobo, V., Patil, A., Phatak, A. and Chandra, N. (2010). Free radicals, antioxidants and functional foods: Impact on human health. Pharmacognosy Reviews, 4
(8), $\quad 118-126$.

https://doi.org/10.4103/09737847.70902

Lopez, D.N., Galante, M., Robson, M., Boeris, V. and Spelzini, D. (2017). Amarath, quinoa and chia protein isolates: Physicochemical and structural properties. International Journal of Biological Macromolecules, 109, 152-159. https:// doi.org/10.1016/j.ijbiomac.2017.12.080

Makinen, S., Johannson, T., Gerd, E.V., Pihlava, J.M. and Pihlanto, A. (2012). Angiotensin I-converting enzyme inhibitory and antioxidant properties of rapeseed hydrolysates. Journal of Functional Foods, $4(3), \quad 575-583 . \quad$ https://doi.org/10.1016/ j.jff.2012.03.003

Malomo, S.A., He, R. and Aluko, R.E. (2014). Structural and functional properties of hemp seed protein products. Journal of Food Science, 79(8), 15121521. https://doi.org/10.1111/1750-3841.12537

Morais, H.A., Silvestre, M.P.C., Silva, V.D.M., Silva, M.R., e Silva, A.C.S. and Silveira, J.N. (2013). Correlation between the degree of hydrolysis and the peptide profile of whey protein concentrate hydrolysates: effect of the enzyme type and reaction time. American Journal of Food Technology, 8(1), 116. https://doi.org/10.3923/ajft.2013.1.16

Munoz, L.A., Cobos, A., Diaz, O. and Aguilera, J.M. (2013). Chia Seed (Salvia hispanica): An ancient grain and a new functional food. Food Reviews International, 29(4), 394-408. https:// doi.org/10.1080/87559129.2013.818014

Najafian, L. and Babji, A.S. (2012). A review of fishderived antioxidant and antimicrobial peptides: Their production, assessment and applications. Peptides, 33(1), 178-185. https://doi.org/10.1016/ j.peptides.2011.11.013

Nam, K.A., You, S.G. and Kim, S.M. (2008). Molecular and physical characteristics of squid (Todarodes pacificus) skin collagens and biological properties of their enzymatic hydrolysates. Journal of Food Science, 73, C249-C255. https://doi.org/10.1111/ j.1750-3841.2008.00722.x

Nitrayova, S., Brestensky, M., Heger, J., Patras, P., Rafay, J. and Sirotkin, A. (2014). Amino acids and fatty acids profile of chia (Salvia hispanica L.) and flax (Linum usitatissimum L.) seed. Potravinarstv, 8, 72-76. https://doi.org/10.5219/332

Nurfatin, M.H., Etty Syarmila, I.K., Nur 'Aliah, D., Zalifah, M.K., Babji, A.S. and Ayob, M.K. (2016). Effect of enzymatic hydrolysis on Angiotensin converting enzyme (ACE) inhibitory activity in swiftlet saliva. International Food Research Journal, 23(1), 141-146. 
Olivos-Lugo, B.L., Valdivia-Lopez M.A. and Tecante, A. (2010). Thermal and physicochemical properties and nutritional value of the protein fraction of Mexican chia seed (Salvia hispanica L.). Food Science and Technology International, 16(1), 89-96. https://doi.org/10.1177/1082013209353087

Pazinatto, C., Pastore, G.M., Malta, L.G. and Netto, F.M. (2013). Antioxidant capacity of amaranth products: Effects of thermal and enzymatic treatments. Food Science and Technology, 33(3), 485-493. https:// doi.org/10.1590/S0101-20612013005000076

Pedroche, J., Yust, M.M., Lqari, H., Giron-Calle, J., Alaiz, M., Vioque, J. and Millan, F. (2004). Brassica carinata protein isolates: Chemical composition, protein characterization and improvement of functional properties by protein hydrolysis. Food Chemistry, 88(3), 337-346. https://doi.org/10.1016/ j.foodchem.2004.01.045

Pihlanto, A. (2006). Antioxidative peptides derived from milk proteins. International Dairy Journal, 16(11), 1306-1314. https://doi.org/10.1016/ j.idairyj.2006.06.005

Phongthai, S., D'Amico, S., Schoenlechner, R., Homthawornchoo, W and Rawdkuen, S. (2018). Fractionation and antioxidant properties of rice bran protein hydrolysates stimulated by in vitro gastrointestinal digestion. Food Chemistry, 240, 156164. https://doi.org/10.1016/j.foodchem.2017.07.080

Poljsak, B., Suput, D. and Milisav, I. (2013). Achieving the balance between ROS and antioxidants: When to use the synthetic antioxidants. Oxidative Medicine and Cellular Longevity, 2013, 956792. https:// doi.org/10.1155/2013/956792

Pouzo, L.B., Descalzo, A.M., Zaritzky, N.E., Rossetti, L. and Pavan, E. (2016). Antioxidant status, lipid and color stability of aged beef from grazing steers supplemented with corn grain and increasing levels of flaxseed. Meat Science, 111, 1-8. https:// doi.org/10.1016/j.meatsci.2015.07.026

Pyne, A.C., Mazzer, A., Clarkson, G.J.J. and Taylor, G. (2013) Antioxidant assays-consistency findings from FRAP and ORAC reveal a negative impact of organic cultivation on antioxidant potential in spinach but not watercress or rocket leaves. Food Science and Nutrition, 1(6), 439-444. https:// doi.org/10.1002/fsn3.71

Rajurkar, N.S. and Hande, S.M. (2011). Estimation of phytochemical content and antioxidant activity of some selected traditional Indian medicinal plants. Indian Journal of Pharmaceutical Science, 73(2), 146-151. https://doi.org/10.4103/0250-474X.91574

Reisner, A.H., Nemes, P. and Bucholtz, C. (1975). The use of Coomassie Brilliant Blue G-250 perchloric acid solution for staining in electrophoresis and isoelectric focusing on polyacrylamide gels. Analytical Biochemistry, 64(2), 509-516. https:// doi.org/10.1016/0003-2697(75)90461-3

Rong, H., Ju, X. and Yuan, J. (2012). Antioxidant activities of rapeseed peptides produced by solid state fermentation. Food Research International, 49 (1), 432-438. https://doi.org/10.1016/ j.foodres.2012.08.023

Rusnakova, M., Hrckova, J.Z.M. and Zemanovic, J. (2002). Enzymatic hydrolysis of defatted soy flour by three different proteases and their effect on the functional properties of resulting protein hydrolysates. Czech Journal of Food Science, 20, 714. https://doi.org/10.17221/3503-CJFS

Samaranayaka, A.G.P. and Li-Chan, E.C.Y. (2011). Autolysis-assisted production of fish protein hydrolysates with antioxidant properties from Pacific hake (Merluccius roductus). Food Chemistry, 107 (2), 768-776. https://doi.org/10.1016/ j.foodchem.2007.08.076

Sandoval-Oliveros, M.R. and Paredez-Lopez, O. (2013). Isolation and characterization of proteins from chia seeds (Salvia hispanica L.). Journal of Agricultural and Food Chemistry, 61(1), 193-201. https:// doi.org/10.1021/jf3034978

Sarmadi, B.H. and Ismail, A. (2010). Antioxidative peptides from food proteins: A review. Peptides, 31 (10), 1949-1956. https://doi.org/10.1016/ j.peptides. 2010.06 .020

Sbroggio, M.F., Montilha, M.S., de Figueirredo, V.R.G. and Georgetti, S.R. (2016). Influence of the degree of hydrolysis and type of enzyme on antioxidant activity of Okara protein hydrolysates. Food Science and Technology (Campinas), 36(2), 375-381. https:// doi.org/10.1590/1678-457X.000216

Segura-Campos, M.R., Espinosa-Garcia, L., ChelGuerrero, L.A. and Betancur-Ancona, D.A. (2012). Effect of enzymatic hydrolysis on solubility, hydrophobicity, and in vivo digestibility in cowpea (Vigna unguiculate). International Journal of Food Properties, 15(4), 770-780. https:// doi.org/10.1080/10942912.2010.501469

Shahi, Z., Sayyed-Alangi, S.Z. and Najafian, L. (2020). Effects of enzyme type and process time on hydrolysis degree, electrophoresis bands and antioxidant properties of hydrolyzed proteins derived from defatted Bunium persicum Bioss. press cake. Heliyon, 6(2), e03365. https://doi.org/10.1016/ j.heliyon.2020.e03365

Shahidi, F. and Zhong, Y. (2008). Bioactive peptides. 
Journal of AOAC International, 91(4), 914-931. https://doi.org/10.1093/jaoac/91.4.914

Shimada, K., Fujikawa, K., Yahara, K. and Nakamura, T. (1992). Antioxidative properties of xanthone on the auto oxidation of soybean in cylcodextrin emulsion. Journal of Agricultural and Food Chemistry, 40, 945 -948. https://doi.org/10.1021/jf00018a005

Taghvaei, M. and Jafari, S.M. (2015). Application and stability of natural antioxidants in edible oils in order to substitute synthetic additives. Journal of Food Science and Technology, 52(3),1272-1282. https:// doi.org/10.1007/s13197-013-1080-1

Thamnarathip, P., Jangchud, K., Nitisinprasert, S. and Vardhanabhuti, B. (2016). Identification of peptide molecular weight from rice bran protein hydrolysate with high antioxidant activity. Journal of Cereal Science, 69, 329-335. https://doi.org/10.1016/ j.jcs.2016.04.011

Tironi, V.A. and Anon, M.C. (2010). Amaranth proteins as a source of antioxidant peptides: Effect of proteolysis. Food Research International, 43(1), 315 -322. https://doi.org/10.1016/j.foodres.2009.10.001

Torucco-Uco, J.G., Mrartinez-Ayala, A.L., Guerrero, L.C. and Davilla-Ortiz, G. (2009). Angiotensin-I converting enzyme inhibitory and antioxidant activities of protein hydrolysates from Phaseolus lunatus and Phaseolus vulgaris seeds. LWT-Food Science and Technology, 42(10), 1597-1604. https:// doi.org/10.1016/j.lwt.2009.06.006

Vilg, J.V. and Undeland, I. (2016). pH-driven solubilization and isoelectric precipitation of proteins from the brown seaweed Saccharina latissimaeffects of osmotic shock, water volume and temperature. Journal of Applied Phycology, 29(1), 585-593. https://doi.org/10.1007/s10811-016-0957-6

Wu, H.C., Chen, H.M. and Shiau, C.Y. (2003). Free amino acids and peptides as related to antioxidant properties in protein hydrolysates of mackerel (Scomber austriasicus). Food Research International, 36(9-10), 949-957. https:// doi.org/10.1016/S0963-9969(03)00104-2

Xiao, P., Huang, H., Chen, Y., Chen, J., Li, X. and Shi, H. (2014) Nutritional evaluation, characterization and antioxidant activity of Radix isatidis protein hydrolysates under stimulated gastrointestinal digestion. Journal of Food and Nutrition Research, 2 (11), 831-838. https://doi.org/10.12691/jfnr-2-11-12

Ye, N., Hu, P., Xu, S., Chen, M., Wang, S., Hong, J., Chen, T. and Cai, T. (2018) Preparation and characterization of antioxidant peptides from carrot seed protein. Journal of Food Quality, 2018, 8579094. https://doi.org/10.1155/2018/8579094
You, L., Zhao, M. and Cui, C. (2009). Effect of degree of hydrolysis on the antioxidant activity of (Misgurnus anguillicaudatus) protein hydrolysates. Innovative Food Science and Emerging Technologies, 10(2), 235-240. https:// doi.org/10.1016/j.ifset.2008.08.007

Zhang, H., Yu, L., Yang, Q., Sun, J., Bi, J., Liu, S., Zhang, C. and Tang, L. (2012). Optimization of a microwave-coupled enzymatic digestion process to prepare peanut peptides. Molecules, 17(5), 56615674. https://doi.org/10.3390/molecules 17055661

Zhao, X.H., Wu, D. and Li, T.J. (2010). Preparation and radical scavenging activity of papain-catalyzed casein plasteins. Dairy Science and Technology, 90 (5), 521-535. https://doi.org/10.1051/dst/2009054 